\title{
RICARDO STERNBERG AND “THIS DREAMT DEPARTURE TO EL DORADO, THE INDIES, THE ISLAND OF HY-BREASIL"
}

\author{
Maria Lúcia Milléo Martins \\ Universidade Federal de Santa Catarina
}

\begin{abstract}
E a ilha desconhecida, perguntou o homem do leme, A ilha
desconhecida não passa duma ideia da tua cabeça, os geógrafos do rei foram ver nos mapas e declararam que ilhas por conhecer é coisa que se acabou desde há muito tempo... (José Saramago, O Conto da Ilha Desconhecida)

A place on the map is also a place in history (Adrienne Rich, "Notes toward a politics of location")
\end{abstract}

Ricardo Sternberg's travel writing ${ }^{1}$ in Map of Dreams weaves myth and history, echoing great voyage narratives like the Odyssey and The Rime of the Ancient Mariner, in a mosaic of other resonances of quests for imaginary islands and real explorations of new worlds. In anticipating in the opening poem, "this dreamt departure to El Dorado, the Indies, the island of Hy-Breasil," Sternberg evokes the very condition of dream fostering adventures to both mythical and tangible lands. El Dorado and the Indies bring to mind the motives of exploration that Paul Fussel identifies as "love of violent adventure, ... mercantile acquisitiveness and the erotics of gold, ... the simple lust for power,

\begin{tabular}{|l|l|l|l|l|}
\hline Ilha do Desterro & Florianópolis & no 57 & p. 129-138 & jul./dez. 2009 \\
\hline
\end{tabular}


often cloaked by a due religious fervor" (25). Hy-Breasil, "an enchanted floating island off the coast of Ireland," oscillates in various accounts of visions and visits. ${ }^{2}$ In its confluence of voices, Map of Dreams is an intriguing hybrid which appropriates and reinvents seafaring myths and explorers' travel writing, in particular the chronicles of Portuguese and Spanish navigation from the time of the great discoveries. This study examines this intertextual play in the book. In doing so, it is attentive to the implications of writing and collage, in James Clifford's sense of these concepts: "the former seen as interactive, open-ended, and processual, the latter as a way of making space for heterogeneity, for historical and political, not simply aesthetic, juxtapositions"(3). Thus, the theme of travel in Map of Dreams is viewed here in the intersection of myth and history, in the diversity of voices and cultural crossings.

The book's epigraph, "Vera quae visa; Quae non, veriora" "True, the seen; the unseen, truer still"), taken from the explorer William Baffin on a map of 1619 , not only questions the boundaries between the imaginative and the real, but the long-established reliance on "the seen" as testimony of truth. This is demonstrated in the beginning of the narrative, when the potential traveler, "a boy on the coast of Ireland" envisions the island:

he would often see it, or thought he did,

- so deep his thirst for that elsewherethe island, floating, half hidden in the salt spray haze of dawn.

Head bowed until its horns

grazed the dirt, dragging the plow through intractable earth, that ox was the prowhead and he himself the ship Clumps of soil, uprooted as they moved, were foam churned by his passing. ("As a boy on the coast," 2-12) 
Then, "tired of this game," he finally reaches Portugal, the voyage's point of departure. Echoing old European navigations, the adventure starts against all odds, with a captain discarding "mechanical gauges" and a blind pilot only guided by his acute sense of smell. The captain's "sustained attention to breath and heartbeat" that allows him to dispense with technology is in fact appropriated from one of Columbus's writings. ${ }^{3}$ The combination of technology and sight obviously indispensable in this kind of adventure is here ironically absent.

In this respect, Alexis Cohen notes that, since the Enlightenment, the Western world has traditionally privileged sight as the most trustworthy lenses between man and world. He then argues that the denial of this idea in Map of Dreams evokes a Medieval belief in other potentials of the human body. ${ }^{4}$ Or perhaps one can argue that it reflects a postmodern disbelief in too much reliance. A consequence of this has been questioning the long legacy of the power of the gaze, or in Pratt's terms, "imperial eyes" authorizing discourses of conquest.

Whichever the case, the narrative consistently deviates from the supremacy of sight to other potentials of human perception. The account of how Gonzago (the pilot) lost his sight illustrates this:

You could say Gonzago was born a sailor for his mother's waters broke, or so he was told, like a violent wave he rode towards this world's harsh light.

And when that light fell from his eyes he learned that to gather unto himself the true wealth of this world a boy need only rely on his nose: ("You could say Gonzago," 1-8)

Another curious resonance in the book regarding old European voyages of exploration is the reference to religion. Lost after the captain 
had disposed of navigation devices, the crew "hammered ...crosses / into crescent moons. / But neither cross nor moon / could replace the charts / the captain had destroyed" ("No soonner had we left," 15-19). Later, when Gonzago was possessed by "small daemons," "it took the Friar / a week of praying / and doses of carminative / administered by the cook" to release his body ("Gonzago, the blind pilot," 22-25). The two references recall the "religious fervor," as Fussel notes, sanctifying or sanctioning the feat of explorers in voyages to new lands. The inefficiency of the religious gesture in the first episode, and its insufficiency in the second (considering the cook's intervention) may be read ironically in regard to the power of religion in voyages of exploration. This is even more suggestive in another episode when, in the middle of a storm, the captain "made bold by rum, raised / his fist to heaven / demanding the storm subside / which, perhaps by coincidence, it did," the ocean then pacified like the sea of biblical Galilee ("And in that maelstrom," 10-16).

As the narrative undermines role models, traditional forms of knowledge and religion, less conventional substitutes, more imaginative and mysterious are proposed. Eccentric like captain and sailor,

Giuseppi from Palermo knew the secrets of the Babylonians,

algebraic incantations that could paralyse the eye,

the symbolic order of colours, the five erotic positions

of the Kingdom of Cathay:

the surnames of the winds that guided good Gonzago, 


\section{the fifth cardinal point, the crystal rhythm of waves, ... ("Giuseppi from Palermo," 1-7, 15-18)}

"It was he as well who identified / the monsters as they rose / out of nightmare." In addition, his knowledge included conventions of trade, languages, and "the science of knots to which / he had himself contributed." Heterogeneity of expertise and cultural diversity on the foreground here leaves backstage the long history of European dominance in the field of knowledge (of course with the due debt of its expansion to explorers and travel writing). In ignoring other forms of knowledge of "the rest of the world," taken as inferior or primitive, European expansionism resulted in what Pratt calls a "Eurocentered form of global or, as [she calls] it, 'planetary' consciousness" (5).

As in magical realism, history is constantly blinking in the most imaginary places. The dialogic character of Map of Dreams with old myths and voyage chronicles favors this intersection. Likewise, the human and the fantastic intertwine in the narrative in many ways, as at the beginning of the adventure, when the ship is adrift and the captain (humanly "rum-drunk") straps himself to the mast, begging "to hear something from the sirens." Less fatal than in the original myth, the sirens' chant merely proposes that they "sail by the power of dreams ... by ignoring maps, / by letting the helm go" ("No soonner had we left," 10-12). Nobody escapes or drowns. Sirens reappear on the pages of the only book aboard "with its registry of monsters," "[taking] delight / in the hiss and spume of surf" ("What was left us then," 1112). As a matter of fact, except for the centaurs on the shore, all other creatures depicted in this registry are female: "the girl: / the glitter of gold is grain in her hand ... / an Amazon astride a reined dolphin / shoots an arrow towards a curved green coast: / my island the shape of a harp!" $(15-16,20-23) .{ }^{5}$ Curiously or perhaps ironically, these creatures who are the only female presence in the adventure, under the label of monsters, offer no threat but the appeal of sensuality, wealth (or "the erotics of gold") and conquest (the latter considering the identification 
of the "curved green coast" with the dreamed island). As we well know, such appeals have in fact become cliché in a constellation of discourses about exploration and conquest, island or land sometimes personifying female sensuality.

Here again history signals and makes us think of the scarcity of women as subjects, agents in the history of travel writing. As Clifford observes, "'Good travel' (heroic, educational, scientific, adventurous, ennobling) is something men (should) do" (31), and of course write about. This is so in Map of Dreams; the whole crew is male. ButSternberg finds an original way to problematize this by bringing mermaids aboard:

Then, it was the mermaids

adrift in our moonlit wake, [who] begged to be brought aboard there to sit, shivering, arms around each other, asking of the sailor that he tell once more the tale of Fergus whom they had drowned.

And once he was done, that he tell it again, the grief in his growl soaking each word, until daybreak neared and, singly, they slipped overboard, to mingle their tears in the salt of the sea. ("A pig-iron disposition," 9-25)

The mermaids are here humanized (or womanized) in an image of fragility_"shivering, / arms around each other," then "[slipping] overboard, to mingle their tears / in the salt of the sea." But they are also shown as powerful creatures for having drowned Fergus. 
Reversing the myth, Sternberg explains that, "instead of the sailors going after the mermaids' chant, the mermaids come aboard to listen to the sailor's story." 6 Perhaps some feminist readers would prefer the mermaids not to beg to come aboard, or not to listen but to tell themselves the tale of Fergus. Anyway, the interactive quality of mermaids and crew aboard makes them participants in the experience of travel, and opens the polemic.

For bringing in the tradition of story-telling, this episode recalls The Canterbury Tales. Critics point out this and other resonances of great voyage narratives. In a review of the book, Cristine Mazur notes that, in invoking a blessing on all sea creatures, the narrative recreates "a truly Melvillian gesture, as the catalogue unfolds similarly to Ishmael's whale 'Folios' in a clear and organized order from ordinary fish to 'all things bivalved."'7 This same passage also evokes a similar one in The Rime of the Ancient Mariner when, after the horrible punishment that follows the killing of the albatross, nature signals redemption with the movements of sea creatures. Sternberg's version finishes with the lines: "Blessed be all things finned, / gilled, scaled and valved: / all things moving through water / as we, through the ocean of dreams" ("Blessed be the life force," 31-34). Still about this passage, Carmine Starnino observes that the poem's cornucopia of sea-life isn't so much the result of a verbal surfeit as a spiritual one," concluding that "the poem's incantatory rhythm also carries the power of a hymn." 8

As the adventure approaches the end, Columbus's voice echoes again to speak of nostalgia for the homeland: "Bien que el coerpo ande acá, el coraçon esta alí de continuo" ("Bien que el cuerpo," 1-2). ${ }^{9}$ His imagination in finding signs of land in everything is also remembered in the lines:

Though I hear nightingales

smell the nectarines,

see honeycombs so laden

their gold overflows 


\section{in a long, continuous tear, \\ I fear I'll not set foot \\ on that green shore. ("Held to a diet," 13-23)}

Gonzago's sharp sense of smell confirms the hallucination, and suddenly "something leaps": "the marmoset / who brought in its fist / the crushed fragrance of the tropics" "The first signs we see," 24-26). The image makes the link between the real and the imaginary in its allusion to lands actually discovered and others that remain drifting in the map of dreams. The adventure then comes to an end with the circularity of return. The (is)land resists conquest and reminds us of others that have surrendered. But, as the poet concludes, the point may not be conquest, not even "a pinpoint on a map / but the map itself. / More than the map, / the drawing of if, / this sailing forth" ("Land forever postponed," 8-12).

As Stephen Yenser observes at the back cover of the book, "from ancient tales through postmodern narratives, the quest for the Wandering Islands, a version of paradise, has been a mainstay of the western literary imagination." For him, Map of Dreams is "a scintillating $\log ^{\prime \prime}$ in this continuity. But also, for its rich intertextual potential, Map of Dreams is an ingenious drawing of history. As such, it invites the reader to go beyond its artistry to observe its dialogic complex of voices and cultural crossings.

\section{Notes}

1. Here I use the term borrowing Mary Louise Pratt's idea, considering it not a closed genre but in "its heterogeneity, and its interactions with other kinds of expression" (11).

2. Sternberg mentions the writings of Roderic O'Flaherty and Morough O'Ley as sources for his references to the island. See notes in Map of Dreams (61). Also called O'Brasil, O'Brassil, Breasil, Brasylle, Hi-Brasil, the island is said to be named after the King of Ireland, Bressal ("Hy" meaning island, and "Breasal" meaning mighty and beautiful in Gaelic). The many records of the island include maps. 
From the nineteenth century on, it appears only in a few ones, since its location could not be verified.

3. Sternberg mentions this in an e-mail message (March 13, 2009) among other comments regarding the intertextual character of the book.

4. Alexis Cohen, "Navigating the Boundaries of the Real: Reason and Imagination in Ricardo Sternberg's Map of Dreams, unpublished paper.

5. Sternberg explains that this image was taken from a Portuguese chronicler who mentions that Brazil has this shape (same e-mail message).

6. Sternberg, same e-mail message.

7. Christine Mazur, 14 April 2009, http://130.179.92.25/Treeline/PINE/ MAR97R1.HTM.

8. Carmine Starnino, 14 April 2009, http://www.booksincanada.com/ article_view.asp?id=51.

9. See Sternberg's note: "Christopher Columbus in a 1502 letter to the Banco di San Giorgio in Genoa," 61. In the e-mail message, Sternberg also acknowledges his use of Columbus's imagination that follows.

\section{References}

Clifford, James. Routes: Travel and Translation in the Late Twentieth Century. Cambridge: Harvard University Press, 1997.

Cohen, Alexis. "Navigating the Boundaries of the Real: Reason and Imagination in Ricardo Sternberg's Map of Dreams." Unpublished paper.

Fussel, Paul, ed. The Norton Book of Travel. New York: W. W. Norton \& Company Ltd., 1987.

Mazur, Cristine. Map of Dreams: Ricardo Sternberg. 14 April 2009. <http:// 130.179.92.25/Treeline/PINE/MAR97R1.HTM>

Pratt, Mary Louise. Imperial Eyes: Studies in Travel Writing and Transculturation. New York: Routledge, 1992. 
138 Maria Lúcia Milléo Martins

Starnino, Carmine. "Giving Good Measure." 14 April 2009 <http:// www.booksincanada.com/article_view.asp?id=51>

Sternberg, Ricardo. Map of Dreams. Montreal: Signal Editions, Véhicule Press, 1996. 